\title{
Novel Fast Degradable Thermosensitive Polymeric Micelles Based on PEG-block-poly(N-(2-hydroxyethyl)methacrylamide-oligolactates)
}

\author{
Cristianne J. F. Rijcken, ${ }^{\dagger}$ Theo F. J. Veldhuis, ${ }^{\dagger}$ Aissa Ramzi, ${ }^{\dagger}$ Johannes D. Meeldijk, ${ }^{\ddagger}$ \\ Cornelus F. van Nostrum,$^{\dagger}$ and Wim E. Hennink ${ }^{*} \dagger$ \\ Department of Pharmaceutics, Utrecht Institute for Pharmaceutical Sciences (UIPS), Utrecht University, \\ P.O. Box 80.082, 3508TB, Utrecht, The Netherlands, and Electron Microscopy Utrecht (EMU), Department \\ of Cell Biology, Utrecht University, Padualaan 8, $3584 \mathrm{CH}$ Utrecht, The Netherlands
}

Received April 15, 2005; Revised Manuscript Received May 11, 2005

\begin{abstract}
The aim of this study was to design a thermosensitive polymeric micelle system with a relatively fast degradation time of around 1 day. These micelles are of interest for the (targeted) delivery of biologically active molecules. Therefore, $N$-(2-hydroxyethyl)methacrylamide-oligolactates (HEMAm-Lac ${ }_{n}$ ) were synthesized and used as building blocks for biodegradable (block co) polymers. $\mathrm{p}\left(\mathrm{HEMAm}-\mathrm{Lac}_{2}\right.$ ) is a thermosensitive polymer with a cloud point $(\mathrm{CP})$ of $22{ }^{\circ} \mathrm{C}$ which could be lowered by copolymerization with HEMAm-Lac 4 . The block copolymer PEG- $b-((80 \%$ HEMAm-Lac 2$)-(20 \%$ HEMAm-Lac 4$))$ selfassembled into compact spherical micelles with an average size of $80 \mathrm{~nm}$ above the $\mathrm{CP}$ of the thermosensitive block $\left(6{ }^{\circ} \mathrm{C}\right)$. Under physiological conditions $\left(\mathrm{pH} 7.4 ; 37^{\circ} \mathrm{C}\right)$, the micelles started to swell after $4 \mathrm{~h}$ and were fully destabilized within $8 \mathrm{~h}$ due to hydrolysis of the lactate side chains. Rapidly degrading thermosensitive polymeric micelles based on PEG- $b-\left(\left(80 \% \mathrm{HEMAm}-\mathrm{Lac}_{2}\right)-\left(20 \% \mathrm{HEMAm}-\mathrm{Lac}_{4}\right)\right)$ have attractive features as a (targeted) drug carrier system for therapeutic applications.
\end{abstract}

\section{Introduction}

Amphiphilic block copolymers can self-assemble in aqueous solutions into micellar structures consisting of a hydrophilic shell and a hydrophobic core. Generally, micelles have a small size and their hydrophobic core can accommodate hydrophobic drugs such as phthalocyanines and paclitaxel. ${ }^{1,2}$ These properties make polymeric micelles excellent drug delivery vehicles. Carriers that are currently under investigation for drug delivery purposes are based on block copolymers of the hydrophilic poly(ethylene glycol) (PEG) and a variety of hydrophobic blocks including polylactide, polyglycolide, poly(lactide-co-glycolide), poly(propylene oxide) (Pluronic), poly(caprolactone), or poly(benzyl aspartate). ${ }^{3}$

The ideal pharmaceutical nanoparticle displays a high drug encapsulation efficiency, protects the incorporated drug against chemical or enzymatic degradation and is able to release its content in a controlled way, preferable upon arrival at its target site. ${ }^{4,5}$ Besides "simple" solubilization of the drug in the hydrophobic core, covalent binding of a drug (e.g., doxorubicin) onto the hydrophobic polymer segment via an enzymatically cleavable spacer ${ }^{6}$ and via acid sensitive linkers ${ }^{3}$ has also been studied to improve and control the drug loading and release properties of polymeric micelles. The hydrophilic block needs to be long enough to provide steric stabilization of the particles and at the same time to give the particle

* To whom correspondence should be addressed. Tel: +31-302536964 Fax +31-302517839. E-mail: W.E.Hennink@pharm.uu.nl.

$\dagger$ Utrecht Institute for Pharmaceutical Sciences (UIPS), Utrecht University.

Electron Microscopy Utrecht (EMU), Utrecht University. "stealth" properties. ${ }^{78}$ After intravenous administration, these long circulating PEGylated colloidal particles $(<200 \mathrm{~nm})$ will extravasate and accumulate in tumors and other pathological areas referred to as the enhanced permeability and retention (EPR) effect. ${ }^{9}$

Special classes of polymers are those that exhibit thermosensitive behavior. Block copolymers composed of a hydrophilic block (PEG) and a thermosensitive block can form polymeric micelles above the cloud point temperature (CP) of the thermosensitive block. This has been demonstrated for PEG-PPO-PEG (Pluronic) $)^{10,11}$ and for PEG- $b$ $\mathrm{p}\left(N\right.$-isopropylacrylamide) (PEG- $b$-pNIPAAm).${ }^{12}$ Recently, biodegradable thermosensitive polymeric micelles based on PEG- $b$-(pNIPAAm- $c o$-( $N$-(2-hydroxypropyl)methacrylamidedilactate) (HPMAm- $\left.\mathrm{Lac}_{2}\right)$ ) and PEG- $b$-(pHPMAm- $\mathrm{Lac}_{2}$ ) were described. ${ }^{13,14}$ These block copolymers formed small $( \pm 55 \mathrm{~nm})$ uniform micelles above the $\mathrm{CP}$ of the thermosensitive block. Under physiological conditions, the hydrophobic lactate side chains of the pHPMAm- $\mathrm{Lac}_{2}$ in the micelles are hydrolyzed. Concomitantly, the $\mathrm{CP}$ gradually increases and passes $37^{\circ} \mathrm{C}$, which is associated with destabilization of the micelles. This process is characterized by an initial swelling of the micelles during the first $60 \mathrm{~h}$ due to an increasing hydrophilicity of the core, followed by dissolution of the micelles after approximately one week of incubation. ${ }^{14}$

The circulation time of nanoparticles in blood, even in the case of PEGylated systems, is restricted in time. With a few exceptions, all long-circulating polymeric nanoparticles are cleared from the systemic circulation of experimental animals within the first $8-10 \mathrm{~h}$ after intravenous administra- 
tion. ${ }^{7,15}$ This implies that the ideal carrier is stable for this time and destabilizes upon arrival at its site of action with a concomitant release of the loaded drug. Consequently, there is a need for fast degrading systems, which completely destabilize within approximately $24 \mathrm{~h}$.

The aim of this study was to design thermosensitive block copolymers that form stable micelles at $37{ }^{\circ} \mathrm{C}$ but which will destabilize within 1 day under physiological conditions. From previous research, it is known that the hydrolysis kinetics of (2-hydroxyethyl)methacrylate-dilactate (HEMA$\mathrm{Lac}_{2}$ ) is five times faster than that of HPMAm-Lac $2 .{ }^{16}$ This kinetic difference is explained by the faster hydrolysis of an ester of a primary alcohol in HEMA-Lac 2 versus a secondary alcohol in the HPMAm-Lac 2 . However, it was shown that HEMA-Lac ${ }_{2}$ was unappropriated as a (co)monomer. The corresponding degraded polymer (HEMA (co)polymer) is not hydrophilic enough to have a $\mathrm{CP}$ above body temperature, which is a prerequisite for the present application. ${ }^{17} \mathrm{It}$ was therefore anticipated that a methacrylamide with a primary alcohol function, viz. $N$-(2-hydroxyethyl)methacrylamide (HEMAm), could be more suitable. This paper describes the synthesis and degradation kinetics of $\mathrm{N}$-(2hydroxyethyl)methacrylamide (HEMAm)-lactate derivatives as well as the synthesis and characterization of (co)polymers of these derivatives. Furthermore, amphiphilic and temperature sensitive block copolymers with poly(ethylene glycol) were synthesized. The micelle forming properties of these block copolymers were studied and subsequently the degradation kinetics of the micelles.

\section{Materials}

Methacryloyl chloride, $\alpha, \alpha$-azoisobutyronitrile (AIBN), 4-methoxyphenol (99\%), lithium chloride ( $\mathrm{LiCl})$, monomethyl ether of poly(ethylene glycol), $M_{\mathrm{w}}$ is $5000 \mathrm{~g} / \mathrm{mol}$ $\left(\mathrm{mPEG}_{5000}\right)$, and pyrene were obtained from Fluka Chemie AG (Buchs, Switzerland). L-Lactide ((3S-cis)-3,6-dimethyl1,4-dioxane-2,5-dione, >99.5\%) was obtained from Purac Biochem BV (Gorinchem, The Netherlands). Ethanolamine (>99\%), stannous 2-ethyl hexanoate (approximately 95\%) and deuterated dimethyl sulfoxide, $\left(99.9 \%\right.$, DMSO- $\left.d_{6}\right)$ were obtained from Acros (Zwijndrecht, The Netherlands). The $\mathrm{PEG}_{2}$-macroinitiator with $\mathrm{mPEG}_{5000}$ was prepared with 4,4azobis(4-cyanopentanoic acid) (ABCPA) as described previously. ${ }^{13}$ Diethyl ether (analytical grade) and triethylamine were obtained from Merck (Darmstadt, Germany). Acetonitrile (HPLC $-\mathrm{S}$, gradient grade), dichloromethane, dimethylformamide (DMF), and 1,4-dioxane were purchased from Biosolve Ltd. (Valkenswaard, The Netherlands). 1,4Dioxane was purified by distillation prior to use. All buffers were filtered through $0.2 \mu \mathrm{m}$ filter (Schleicher \& Schuell MicroScience GmbH, Dassel, Germany) prior to use. The other chemicals were used as received.

\section{Methods}

Synthesis of HEMAm and HEMAm-Lac $n$. $N$-(2-Hydroxyethyl)methacrylamide (HEMAm) was synthesized essentially as described by Song et al. ${ }^{18}$ In brief, freshly distilled

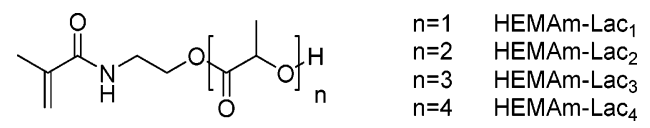

Figure 1. $\mathrm{N}$-(2-Hydroxyethyl)methacrylamide (HEMAm)- oligolactates.

methacryloyl chloride (130 mL, $1.34 \mathrm{~mol}$ ) dissolved in 250 $\mathrm{mL}$ of dichloromethane was added dropwise to an ice-cold solution of 2-aminoethanol $(162 \mathrm{~mL}, 2.68 \mathrm{~mol})$ and triethylamine (109 mL, $1.47 \mathrm{~mole})$ in $250 \mathrm{~mL}$ of dichloromethane in $3 \mathrm{~h}$ under a nitrogen atmosphere. Subsequently, the mixture was stirred overnight at room temperature under a nitrogen atmosphere. The crude product was filtered and purified by flash chromatography using dichloromethane/ methanol $(85 / 15)$ as the eluent $\left(R_{\mathrm{f}}=0.45\right)$.

The oligolactate derivatives of HEMAm were synthesized via the procedure as reported by Van Dijk-Wolthuis et al. ${ }^{19}$ Briefly, L-lactide $(33.5 \mathrm{~g}$; $0.233 \mathrm{~mol})$ and HEMAm $(20 \mathrm{~g}$; $0.155 \mathrm{~mol}$ ) were stirred at $110{ }^{\circ} \mathrm{C}$ until the lactide was molten. 4-Methoxyphenol ( $\sim 0.1$ mol \% relative to HEMAm) was added as a radical scavenger. Subsequently, a catalytic amount of stannous 2-ethyl hexanoate $(630 \mathrm{mg} ; 1 \mathrm{~mol} \%$ relative to HEMAm) was added. The resulting mixture was stirred for $2 \mathrm{~h}$ and allowed to cool to room temperature. After dissolution of the product in $250 \mathrm{~mL}$ of water-acetonitrile (50:50), the HEMAm-oligolactate was fractionated with preparative chromatography essentially as described by Neradovic et al. ${ }^{16}$ In detail, the HPLC system (Waters Associates Inc., Milford, MA) consisted of a pump model 600 , a variable wavelength absorbance detector model 2487, a sample manager model 2700, and a Xterra Prep MS C18 $(10 \mu \mathrm{m}, 19 \times 250 \mathrm{~mm}$ i.d.) with a Xterra Prep MS C18 guard column $(19 \times 10 \mathrm{~mm})$ was used. The injection volume was $5 \mathrm{~mL}$ and the detection wavelength was 254 and 280 $\mathrm{nm}$. A gradient was run using water/acetonitrile $=95: 5(\mathrm{w} /$ w) (eluent A) and acetonitrile/water $=95: 5(\mathrm{w} / \mathrm{w})$ (eluent B) from $0 \% \mathrm{~B}$ to $50 \% \mathrm{~B}$ in 35 min with a flow rate of 10.0 $\mathrm{mL} / \mathrm{min}$. Four fractions were collected, and after evaporation of the solvents, the identity of the obtained products, HEMAm mono-, di,- tri-, and tetralactate (further abbreviated as HEMAm-Lac 1 , HEMAm- $\mathrm{Lac}_{2}, \mathrm{HEMAm}-\mathrm{Lac}_{3}$, and HEMAm-Lac 4 ; see Figure 1), was established by NMR; the purity was assessed by HPLC (system as described below).

${ }^{1} \mathrm{H}$ NMR Spectroscopy. ${ }^{1} \mathrm{H}$ NMR spectra were recorded with a Gemini $300 \mathrm{MHz}$ spectrometer (Varian Associates Inc., NMR Instruments, Palo Alto, CA). Spectra were obtained in DMSO- $d_{6}$. The central line of DMSO at 2.49 ppm was used as reference line.

Hydrolysis Kinetics of HEMAm-Oligolactates. The degradation studies of HEMAm-oligolactates were conducted according to the procedure as described by Neradovic et al. ${ }^{16}$ In brief, a $10 \mathrm{mM}$ solution of HEMAm-oligolactate in DMSO was diluted 10 times with phosphate buffer $\mathrm{pH} 7.2$ $(100 \mathrm{mM})$ in a glass vial and the $\mathrm{pH}$ was adjusted to $\mathrm{pH} 7.4$ with $4 \mathrm{M} \mathrm{HCl}$. The resulting solutions of HEMAm- $\mathrm{Lac}_{1}$, HEMAm- $\mathrm{Lac}_{2}, \mathrm{HEMAm}-\mathrm{Lac}_{3}$, and HEMAm- $\mathrm{Lac}_{4}$ were incubated in a water bath at $37^{\circ} \mathrm{C}$. At regular time intervals, samples of $300 \mu \mathrm{L}$ were withdrawn and $700 \mu \mathrm{L}$ of $1 \mathrm{M}$ sodium acetate buffer ( $\mathrm{pH}$ 3.8) was added to prevent further 
hydrolysis. The samples were stored at $4{ }^{\circ} \mathrm{C}$ prior to HPLC analysis. The hydrolysis of HEMAm $-\mathrm{Lac}_{3}$ and HEMAm$\mathrm{Lac}_{4}$ was also investigated in an acetonitrile-phosphate buffer $\mathrm{pH} 7.2(100 \mathrm{mM})$ mixture $(50: 50 \mathrm{w} / \mathrm{w})$ to compare the kinetic data with previous results..$^{20}$ HPLC analysis was carried out on a Waters system (Waters Associates Inc., Milford, MA) consisting of a pump model 600, an autoinjector model 717, a variable wavelength absorbance detector model 996, and an analytical reversed phase column LiChrosphere $100 \mathrm{RP}-18(5 \mu \mathrm{m}, 125 \times 4 \mathrm{~mm}$ i.d. $)$ with a RP-18 guard column $(4 \times 4 \mathrm{~mm})$ (Merck). The injection volume was $50 \mu \mathrm{L}$ and the detection wavelength was 254 $\mathrm{nm}$. After $5 \mathrm{~min}$ isocratic flow of water/acetonitrile $=95: 5$ (w/w), (eluent A), a gradient was run using $100 \%$ eluent A to $100 \%$ acetonitrile/water $=95: 5(\mathrm{w} / \mathrm{w})$, (eluent $\mathrm{B})$ in 30 min with a flow rate of $1.0 \mathrm{~mL} / \mathrm{min}$. The chromatograms were analyzed with Empower Software Version 1154 (Waters Associates Inc.). Calibration curves were generated for each monomer and for HEMAm with freshly prepared standard solutions in DMSO/pH 7.2 phosphate buffer (100 $\mathrm{mM}) /$ sodium acetate buffer $\mathrm{pH} 3.8(1 \mathrm{M})(3: 27: 70)$ and were linear between 0.07 and $15 \mu \mathrm{M}$.

Synthesis of (co)-Polymers of HEMAm-Oligolactates. Homopolymers (HEMAm, HEMAm- $-\mathrm{Lac}_{n}$ ) and copolymers (mixtures of HEMAm- $\mathrm{Lac}_{2}$ and HEMAm- $\mathrm{Lac}_{4}$ ) were synthesized by free radical polymerization in airtight screwcap glass vials. AIBN dissolved in 1,4-dioxane (ratio of monomers/initiator $=75-150 \mathrm{~mol} / \mathrm{mol}$ ) was added to 200 $\mathrm{mg}$ monomer dissolved in $1 \mathrm{~mL}$ of dioxane. After addition of the initiator, the solution was flushed with nitrogen for at least $10 \mathrm{~min}$. Next, the solution was heated to $70{ }^{\circ} \mathrm{C}$ and stirred for $24 \mathrm{~h}$. The polymers were precipitated by dropwise addition of the solution to an excess of diethyl ether. After centrifugation, the residue was dried overnight in a vacuum oven at $40{ }^{\circ} \mathrm{C}$.

${ }^{1} \mathrm{H}$ NMR (DMSO, $\left.d_{6}\right): \delta=7.5(\mathrm{~b}, \mathrm{CO}-\mathrm{N} H-\mathrm{CH} 2), 5.5$ (b, $\mathrm{CH}-\mathrm{OH}), 5.0(\mathrm{~b}, \mathrm{CO}-\mathrm{CH}(\mathrm{CH} 3)-\mathrm{O}), 4.1$ (b, $\mathrm{CO}-\mathrm{CH}-$ (CH3)-OH), 4.0 (b, CH2-CH2-O), 3.4 (b, NH-CH2$\mathrm{CH} 2), 1.4,(\mathrm{~b}, \mathrm{CO}-\mathrm{CH}-\mathrm{CH} 3), 1.3$ (b, HO- $\mathrm{CH}-\mathrm{CH} 3), 1.0-$ 0.6 (pHEMAm $-\mathrm{Lac}_{n}$ main chain protons).

The HEMAm- $\mathrm{Lac}_{2} / \mathrm{HEMAm}-\mathrm{Lac}_{4}$ comonomer ratio ( $\mathrm{mol} / \mathrm{mol})$ in the copolymer was determined by ${ }^{1} \mathrm{H}$ NMR from the ratio of the integral of the methine protons $\left(\mathrm{H}_{\mathrm{h}}\right.$; $\delta=5.0 \mathrm{ppm})$ to the alcoholic proton $\left(\mathrm{H}_{\mathrm{oh}} \delta=5.5 \mathrm{ppm}\right)$. The following equation was used:

$$
\% \text { HEMAm }-\mathrm{Lac}_{4}=\left(\left(I_{\mathrm{Hh}}-I_{\mathrm{Hoh}}\right) / 2\right) \times 100 \%
$$

Synthesis of Poly(HEMAm-Lac $\left.{ }_{\mathbf{n}}\right)-\boldsymbol{b}$ - PEG $_{5000}$. Block copolymers with HEMAm- $\mathrm{Lac}_{n}$ as thermosensitive block and PEG as hydrophilic block were prepared by radical polymerization using $\mathrm{PEG}_{2}-\mathrm{ABCPA}$ as macroinitiator (ratio of monomer/initiator $=150: 1 \mathrm{~mol} / \mathrm{mol}$ ) according to the procedure as previously described for the synthesis of related block copolymers. ${ }^{13,14}$ The concentration of the starting materials (monomer plus macroinitiator) was $300 \mathrm{mg} / \mathrm{mL}$ in acetonitrile in airtight glass vials. The solution was flushed with nitrogen for at least $10 \mathrm{~min}$, heated to $70^{\circ} \mathrm{C}$, and stirred for $24 \mathrm{~h}$. Next, by dropwise addition of the solution to an excess of diethyl ether, the polymers were precipitated. After centrifugation, the residue was dried overnight in a vacuum oven at $40{ }^{\circ} \mathrm{C}$.

${ }^{1} \mathrm{H}$ NMR (DMSO, $\left.d_{6}\right): \delta=7.5(\mathrm{~b}, \mathrm{CO}-\mathrm{NH}-\mathrm{CH} 2), 5.5$ (b, $\mathrm{CH}-\mathrm{OH}), 5.0$ (b, $\mathrm{CO}-\mathrm{CH}(\mathrm{CH} 3)-\mathrm{O}), 4.1$ (b, $\mathrm{CO}-\mathrm{CH}-$ (CH3)-OH), 4.0 (b, CH2-CH2-O), 3.6 (b, PEG methylene protons, $\mathrm{O}-\mathrm{CH} 2-\mathrm{CH} 2$ ), 3.4 (b, $\mathrm{NH}-\mathrm{CH} 2-\mathrm{CH} 2$ ), 1.4, (b, $\mathrm{CO}-\mathrm{CH}-\mathrm{CH} 3$ ), 1.3 (b,HO-CH-CH3), 1.0-0.6 (pHE$\mathrm{MAm}-\mathrm{Lac}_{n}$ main chain protons).

The number average molecular weight $\left(M_{\mathrm{n}}\right)$ of the thermosensitive block was determined by ${ }^{1} \mathrm{H}$ NMR as follows (in the situation of copolymers, an average molecular weight of the monomers was used):

$$
M_{\mathrm{n}}=\mathrm{Mw}_{\mathrm{ave}}\left(\mathrm{HEMAm}-\mathrm{Lac}_{n}\right) I_{\mathrm{HEMAm}-\mathrm{Lacn}} /\left(I_{\mathrm{PEG}} / 454\right)
$$

$I_{\text {HEMAm-Lacn }}$ is the value of the integral of the alcoholic proton of the HEMAm $-\mathrm{Lac}_{n}\left(\mathrm{H}_{\mathrm{oh}} \delta=5.5 \mathrm{ppm}\right) ; I_{\mathrm{PEG}}$ is the value of the integral of the PEG protons divided by average number of protons per one $\mathrm{PEG}_{5000}$ chain (=454).

Gel Permeation Chromatography (GPC). The molecular weights and their distribution of the different polymers were determined by GPC. Two serial Plgel $3 \mu \mathrm{m}$ MIXED-D columns (Polymer Laboratories) were used with a Waters System (Waters Associates Inc., Milford, MA) with a differential refractometer model 410. Poly(ethylene glycol)s of defined molecular weights were used as standards. The eluent was DMF containing $10 \mathrm{mM} \mathrm{LiCl}{ }^{21}$ The samples were dissolved overnight at a concentration of $5 \mathrm{mg} / \mathrm{mL}$ in the eluent and filtered through a $0.45 \mu \mathrm{m}$ filter prior to analysis. The flow rate was $0.7 \mathrm{~mL} / \mathrm{min}$ and the column temperature was $40{ }^{\circ} \mathrm{C}$. Peak areas were determined with Empower Software Version 1154 (Waters Associates Inc).

Determination of the Cloud Point (CP) of (block co) Polymers. The $\mathrm{CP}$ of the synthesized (block co) polymers in aqueous solutions was determined with static light scattering using a Horiba Flurolog fluorometer $\left(650 \mathrm{~nm}, 90^{\circ}\right.$ angle)..$^{13,14,22}$ The polymers were dissolved overnight at $4{ }^{\circ} \mathrm{C}$ in ammonium acetate buffer $(\mathrm{pH} 5,120 \mathrm{mM})$ at a concentration of 1 and $2 \mathrm{mg} / \mathrm{mL}$ for the copolymers and the block copolymers, respectively. The scattering intensity was measured every $0.2^{\circ} \mathrm{C}$ during heating (heating rate approximately $1{ }^{\circ} \mathrm{C} / \mathrm{min}$ ) thereby stirring the solution in the cuvette. The onset on the $X$ axis, obtained by extrapolation of the intensity-temperatures curves to intensity zero, was considered as the $\mathrm{CP}$. The $\mathrm{CP}$ determinations were done at least two times and the deviations were smaller than $1{ }^{\circ} \mathrm{C}$.

Micelle Formation. Micelles were formed via the quick heating procedure as described previously. ${ }^{14}$ In brief, the block copolymers were dissolved overnight at $4{ }^{\circ} \mathrm{C}$ at various concentrations in ammonium acetate buffer $(\mathrm{pH} 5,120 \mathrm{mM})$. The solutions were incubated at $0{ }^{\circ} \mathrm{C}$ for at least $15 \mathrm{~min}$ in glass vials. Subsequently, the vials were rapidly heated from 0 to $50^{\circ} \mathrm{C}$ by putting them into a water bath under vigorous stirring to form micelles. After $1 \mathrm{~min}$ of incubation at 50 ${ }^{\circ} \mathrm{C}$, the mixtures were slowly cooled to room temperature and filtrated through a $0.22 \mu \mathrm{m}$ filter.

Dynamic Light Scattering (DLS) and Static Light Scattering (SLS). Dynamic and static light scattering (DLS and SLS, respectively) were used to characterize the polymeric micelles. The equipment consisted of a Malvern CGS-3 
multi-angle goniometer (Malvern Ltd,. Malvern, U.K.) with $\mathrm{He}-\mathrm{Ne}$ JDS Uniphase laser $(\lambda=632.8 \mathrm{~nm}, 22 \mathrm{~mW}$ output power), an optical fiber based detector, a digital LV/LSE5003 correlator, and a temperature controller (Julabo Waterbath). Time correlation functions were analyzed using the ALV-60 $\times 0$ Software V.3.X provided by Malvern.

DLS provides the hydrodynamic radius using the StokesEinstein equation

$$
\mathrm{R}_{\mathrm{h}}=\left(k_{\mathrm{B}} \mathrm{T} \cdot \mathrm{q}^{2}\right) /(6 \pi \eta \Gamma)
$$

where $k_{\mathrm{B}}$ is the Boltzmann constant, $q$ is the scattering vector, $(q=(4 \pi n \sin (\theta / 2)) / \lambda$, where $n$ is the refractive index of the solution, $\theta$ is the scattering angle, and $\lambda$ is the wavelength of the incident laser light), $\eta$ is the solvent viscosity, and $\Gamma$ is the decay rate.

Scattering of the micellar solutions was measured at an angle of $90^{\circ}$ at $25^{\circ} \mathrm{C}$ in an optical quality $8 \mathrm{~mL}$ borosilicate cell giving arise to the hydrodynamic diameter $\left(Z_{\text {ave }}=2 R_{\mathrm{h}}\right)$ of the micelles and their polydispersity (PD). The destabilization behavior of the polymeric micelles was studied at 2 $\mathrm{mg} / \mathrm{mL}$ in phosphate buffer $(\mathrm{pH} 7.4,100 \mathrm{mM})$. A cell with approximately $1 \mathrm{~mL}$ micellar solution was incubated in the DLS machine at $37{ }^{\circ} \mathrm{C}$ and measured at regular time intervals.

The radius of gyration $\left(R_{\mathrm{g}}\right)$ and the aggregation number $\left(N_{\text {agg }}\right)$ are two important physical parameters commonly used to describe the characteristics of (polymeric) micelles. The scattered intensities of the polymer solutions at different angles (between $30^{\circ}$ and $150^{\circ}$ ) and concentrations were analyzed by the graphical method first reported by Zimm. ${ }^{23}$ This method involves simultaneously the extrapolation of the scattering data to both zero angle and zero concentrations. The relationship between the concentration and the intensity of the scattered light is given by the following equation:

$$
\frac{K c}{R(q)}=\frac{1}{M_{W}}\left(1+\frac{1}{3} R_{\mathrm{g}}^{2} q^{2}\right)+2 A_{2} c
$$

where $c$ is the concentration, $M_{\mathrm{w}}$ is the weight average molecular weight of the micelles, $R_{\mathrm{g}}$ is the radius of gyration, $A_{2}$ is the second virial coefficient, and $R(q)$ is the excess Rayleigh ratio of the solute (excess intensity of scattered light at scattering vector $q$ ).

The optical constant $K$ is defined as

$$
K=\frac{4 \pi^{2}}{N_{\mathrm{A}} \lambda^{4}} n_{\mathrm{T}}^{2}\left(\frac{\mathrm{d} n}{\mathrm{~d} c}\right)^{2}
$$

where $n_{\text {tol }}$ is the refractive index of toluene (1.494), $(\mathrm{d} n / \mathrm{d} c)$ the specific refractive index increment of the micellar solution, $N_{\mathrm{A}}$ is the Avogadro's constant. The parameter $\mathrm{d} n /$ $\mathrm{d} c$ was here estimated to be 0.1 based on previous experiments on PEG- $b$-(HPMAm- $\left.\mathrm{Lac}_{2}\right){ }^{14}$ The absolute excess time-averaged scattered intensity, i.e., Rayleigh ratio $R(q)$ is expressed by the equation

$$
R(q)=R_{\mathrm{tol}, 90}\left(\frac{n}{n_{\mathrm{tol}}}\right)^{2 I-I_{0}} \frac{I_{\mathrm{tol}}}{I_{\mathrm{f}}} \sin (\theta)
$$

where $R_{\mathrm{tol}, 90}$ is the Rayleigh ratio of toluene at an angle of $90^{\circ}$ and amounts $13.7 \times 10^{-6} \mathrm{~cm}^{-1}, n$ is the refractive index of the solvent, $I, I_{\mathrm{o}}$, and $I_{\mathrm{tol}}$ are the scattered intensities of the solution, solvent, and toluene, respectively, and $\theta$ is the measurement angle.

Critical Micelle Concentration (CMC). The CMC of the block copolymers was determined using pyrene as a fluorescent probe. ${ }^{24}$ Micelles of the different block copolymers were formed as described above in $120 \mathrm{mM}$ ammonium acetate buffer ( $\mathrm{pH} \mathrm{5.0)}$ at a concentration of $2 \mathrm{mg} / \mathrm{mL}$. The micellar solutions were cooled to room temperature and subsequently diluted with the same buffer yielding different polymer concentrations ranging from $1 \times 10^{-5}$ to $1 \mathrm{mg} / \mathrm{mL}$. Next, $15 \mu \mathrm{lLof}$ pyrene dissolved in acetone (concentration $1.8 \times 10^{-4} \mathrm{M}$ ) was added to $4.5 \mathrm{~mL}$ of polymer solution (final pyrene concentration $6 \times 10^{-7} \mathrm{M}$ ). Samples were incubated for $15 \mathrm{~h}$ at room temperature in the dark to allow equilibration of the samples. Prior to the measurements, the solutions were incubated at $37{ }^{\circ} \mathrm{C}$ for at least $15 \mathrm{~min}$. Fluorescence excitation spectra of pyrene were obtained using a Horiba Fluorolog fluorometer $\left(90{ }^{\circ} \mathrm{C}\right.$ angle). The excitation spectra were recorded at $37{ }^{\circ} \mathrm{C}$ from $300-360$ $\mathrm{nm}$ with the emission wavelength at $390 \mathrm{~nm}$. The excitation and emission band slits were 4 and $2 \mathrm{~nm}$, respectively. The intensity ratio of $I_{338} / I_{333}$ was plotted against the polymer concentration to determine the CMC.

Cryogenic Transmission Electron Microscopy (CryoTEM). Cryo-TEM measurements were performed on $2 \mathrm{mg} /$ $\mathrm{mL}$ micellar solutions in $120 \mathrm{mM}$ ammonium acetate buffer (pH 5.0). The sample preparation was done in a temperature and humidity controlled chamber using a "Vitrobot". A thin aqueous film of micellar solution was formed by blotting a 200 mesh copper grid covered with Quantifoil holey carbon foil (Micro Tools $\mathrm{GmbH}$, Germany) at $22{ }^{\circ} \mathrm{C}$ and at $100 \%$ relative humidity (glow discharged grid; 1 blot during 0.5 $\mathrm{s})$. The thin film was rapidly vitrified by quickly plunging the grid into liquid ethane. The grids with the vitrified thin films were transferred into the microscope chamber using a GATAN 626 cryo-holder system. A Tecnai12 transmission electron microscope (Philips) operating at $120 \mathrm{kV}$ was used with the specimen at $-180{ }^{\circ} \mathrm{C}$ and using low-dose imaging conditions to avoid melting of the vitrified film. Images were recorded on a SIS-CCD camera and processed with AnalySIS software. Images were taken of micelles captured in the thin vitrified liquid film in the holes of the carbon foil to image them as undisturbed as possible.

\section{Results}

Synthesis of HEMAm and HEMAm- $\mathbf{L a c}_{n} \cdot N-(2-\mathrm{Hy}-$ droxyethyl)methacrylamide (HEMAm) was synthesized by the reaction of ethanolamine with methacryloyl chloride. ${ }^{18}$ After column chromatography, the product was obtained in a high yield $(85 \%)$ as a light-yellow oil and a high purity (>95\%, NMR). Oligolactate esters of $N$-(2-hydroxyethyl)methacrylamide (HEMAm-oligolactate) were obtained by ring-opening oligomerization of L-lactide, using HEMAm as the initiator and stannous 2-ethyl hexanoate as a catalyst. ${ }^{17}$ HEMAm- $-\mathrm{Lac}_{1}$ to HEMAm-Lac 4 (Figure 1) were obtained with high purity and good yield $(\sim 50 \%)$ after fractionation with a preparative HPLC system. 
Table 1. Degradation Kinetics of HEMAm-Oligolactates and Related Structures at $37^{\circ} \mathrm{C}$

\begin{tabular}{lcclcc}
\hline \multicolumn{1}{c}{ monomer } & pH & cosolvent \% & $\begin{array}{c}\text { primary } \\
\text { hydrolysis } \\
\text { product }\end{array}$ & $\begin{array}{c}\mathrm{t}_{1 / 2} \\
(\mathrm{~h})^{a}\end{array}$ & ref \\
\hline HEMAm-Lac & 7.4 & $10 \%$ DMSO & HEMAm & 58 & this work \\
HEMAm-Lac & 7.4 & $10 \%$ DMSO & HEMAm & 5.6 & this work \\
HEMAm-Lac & 7.4 & $10 \%$ DMSO & HEMAm-Lac & 0.63 & this work \\
HEMAm-Lac & 7.4 & $10 \%$ DMSO & HEMAm-Lac & 0.49 & this work \\
HEMAm-Lac & 7.4 & $50 \%$ ACN & HEMAm-Lac & 4.2 & this work \\
HEMAm- Lac & 7.4 & $50 \%$ ACN & HEMAm-Lac & 3.4 & this work \\
HEMA-Lac & 7.5 & $10 \%$ DMSO & HEMA & 31 & 16 \\
HEMA-Lac & 7.5 & $10 \%$ DMSO & HEMA & 3 & 16 \\
HPMAm-Lac & 7.5 & $10 \%$ DMSO & HPMAm & 87 & 16 \\
HPMAm-Lac & 7.5 & $10 \%$ DMSO & HPMAm & 15 & 16 \\
HPMAm-Lac & 7.4 & $50 \%$ ACN & HPMAm-Lac & 3.1 & 20 \\
HPMAm-Lac & 7.4 & $50 \%$ ACN & HPMAm-Lac & 3.1 & 20 \\
\hline
\end{tabular}

${ }^{a}$ Experimental error is about $5 \%$.

Degradation Kinetics of HEMAm-Oligolactates. The monodisperse HEMAm-oligolactates (Figure 1) hydrolyzed when incubated at $\mathrm{pH} 7.4$ and at $37^{\circ} \mathrm{C}$ and followed pseudofirst-order kinetics with HEMAm and lactic acid as final degradation products. The concentrations of HEMAm- $\mathrm{Lac}_{1}$ to HEMam-Lac 4 were determined by HPLC. From the concentration versus time plots, the half-lives $\left(t_{1 / 2}\right)$ were determined (Table 1). The buffer solution used for the degradation studies also contained DMSO (10\%) to solubilize the oligolactates. Therefore, the half-lives in pure water are expected to be less (approximately halved) than the reported values, as discussed by Neradovic. ${ }^{16}$ Since the formation of methacrylic acid was not detected, it is concluded that the amide bond in HEMAm (-oligolactates) is highly stable under the selected conditions. Table 1 shows that the halflives of HEMAm- $\mathrm{Lac}_{1}$ and HEMAm- $\mathrm{Lac}_{2}$ are 58 and 5.6 $\mathrm{h}$, respectively. The about 10 times faster degradation rate of the dilactate as compared to the monolactate was also observed for HEMA-lactates ${ }^{16}$ and can be explained by intramolecular transesterification, also known as "backbiting". ${ }^{25}$ The possibility of two lactic acid units to form an intermediate six-membered ring structure increases the hydrolysis rate. HEMAm- $\mathrm{Lac}_{1}$ is not able to form a ring intermediate and is accordingly hydrolyzed with a slower rate.

At similar conditions ( $\mathrm{pH} 7.5,10 \%$ DMSO), the half-lives of the methacrylate analogues of HEMAm-lactates, i.e., (2hydroxyethyl)methacrylate (HEMA) mono- and dilactate, were 31 and $3 \mathrm{~h}$, respectively ${ }^{16}$ indicating that HEMAm$\mathrm{Lac}_{1}$ and HEMAm- $\mathrm{Lac}_{2}$ are slightly more stable (half-lives 58 and $5.6 \mathrm{~h}$, respectively). In contrast, the half-lives of HPMAm- $\mathrm{Lac}_{1}$ and HPMAm- $\mathrm{Lac}_{2}$ are 87 and $15 \mathrm{~h}$, respectively. This higher stability of esters of secondary alcohols (HPMAm- $\mathrm{Lac}_{n}$ ) compared to esters of primary alcohols (HEMA-Lac ${ }_{n}$ and HEMAm- $-\mathrm{Lac}_{n}$ ) can be ascribed to steric effects. It has been reported that the presence of increasingly branched aliphatic groups has a retarding influence on the alkaline catalyzed hydrolysis of esters. ${ }^{25}$

HEMAm derivatives with three and four lactic acid units (HEMAm- $\mathrm{Lac}_{3}$ and HEMAm- $\mathrm{Lac}_{4}$ ) displayed faster hydrolysis kinetics than HEMAm-Lac $1-2$. Again, this fast degradation is caused by the back biting mechanism. The HPLC analysis clearly showed that HEMAm- $\mathrm{Lac}_{n}$ is primarily converted into HEMAm- $\mathrm{Lac}_{\mathrm{n}-2}$ as an intermediate product that is ultimately converted into HEMAm. To

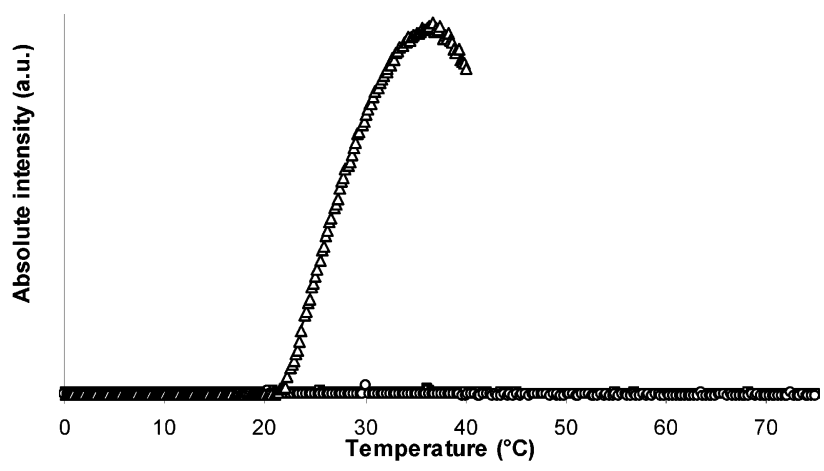

Figure 2. Scattering behavior of $\mathrm{p}(\mathrm{HEMAm})(\square), \mathrm{p}\left(\mathrm{HEMAm}-\mathrm{Lac}_{1}\right)$ $(O)$ and $\mathrm{p}\left(\mathrm{HEMAm}-\mathrm{Lac}_{2}\right)(\triangle)$.

Table 2. Characteristics of the Homopolymers of HEMAm-Lac

\begin{tabular}{lrcccr}
\hline \multicolumn{1}{c}{ monomer } & \multicolumn{1}{c}{$\begin{array}{c}\text { ratio } \\
\mathrm{M} /[\mathrm{l}]\end{array}$} & $\begin{array}{c}\text { yield } \\
(\%)\end{array}$ & $\begin{array}{c}M_{\mathrm{w}} \\
(\mathrm{GPC})\end{array}$ & $M_{\mathrm{w}} / M_{\mathrm{n}}$ & $\begin{array}{r}\mathrm{CP} \\
\left({ }^{\circ} \mathrm{C}\right)\end{array}$ \\
\hline HEMAm & $150: 1$ & 92 & 24000 & 3.7 & $>75$ \\
HEMAm-Lac & $150: 1$ & 71 & 53000 & 3.1 & $>75$ \\
HEMAm-Lac & $100: 1$ & 81 & 68000 & 3.0 & 22 \\
HEMAm-Lac & $75: 1$ & 83 & 24000 & 3.3 & $<0$ \\
HEMAm-Lac & $100: 1$ & 76 & 59000 & 2.6 & $<0$ \\
\hline
\end{tabular}

compare our results with the half-lives obtained for the previously reported HPMAm $-\mathrm{Lac}_{7}$ and HPMAm $-\mathrm{Lac}_{12},{ }^{20}$ the degradation experiments were also carried out with acetonitrile as cosolvent. The half-lives of both HPMAm$\mathrm{Lac}_{7}$ and HPMAm- $\mathrm{Lac}_{12}$ were $3.1 \mathrm{~h}$, which are close to those of HEMAm- $\mathrm{Lac}_{3}$ and HEMAm-Lac 4 (4.2 and 3.4 $\mathrm{h}$, respectively). Taken together, the degradation data of the monomers showed that, as anticipated, the hydrolysis of HEMAm- $\mathrm{Lac}_{n}$ into HEMAm is faster than the time scale wherein HPMAm- $\mathrm{Lac}_{n}$ is converted into HPMAm.

Homopolymers of HEMAm-Lac : Synthesis and Characterization. Free radical polymerization of HEMAm$\mathrm{Lac}_{n}$ in dioxane yielded the corresponding polymers. Table 2 summarizes their properties.

pHEMAm and the pHEMAm-oligolactates were obtained in high yields (around 80\%) under the selected polymerization conditions. The molecular weights were between 24000 and $68000 \mathrm{~g} / \mathrm{mol}$ with a polydispersity $\left(M_{\mathrm{w}} / M_{\mathrm{n}}\right)$ of about 3 , which is standard for polymers synthesized by free radical polymerization. The thermosensitive properties of the polymers were investigated by static light scattering. To prevent hydrolysis of the lactic acid side chains, the polymers were dissolved in a $\mathrm{pH} 5$ buffer at a concentration of $1 \mathrm{mg} / \mathrm{mL}$. $\mathrm{p}\left(\mathrm{HEMAm}-\mathrm{Lac}_{3}\right)$ and $\mathrm{p}\left(\mathrm{HEMAm}-\mathrm{Lac}_{4}\right)$ did not dissolve at $0{ }^{\circ} \mathrm{C}$, suggesting that the cloud point of these polymers is below this temperature. The scattering behavior of $p(\mathrm{HE}-$ MAm), p(HEMAm- $\left.\mathrm{Lac}_{1}\right)$, and $\mathrm{p}\left(\mathrm{HEMAm}-\mathrm{Lac}_{2}\right)$ solutions is displayed in Figure 2.

$\mathrm{p}(\mathrm{HEMAm})$ and $\mathrm{p}\left(\mathrm{HEMAm}-\mathrm{Lac}_{1}\right)$ were well soluble in water and did not show any scattering up to $75{ }^{\circ} \mathrm{C}$. An aqueous solution of $\mathrm{p}\left(\mathrm{HEMAm}-\mathrm{Lac}_{2}\right)$ showed a sharp increase in scattering intensity when the temperature was increased above $22^{\circ} \mathrm{C}$, demonstrating that this polymer has temperature sensitive properties. Figure 2 shows that the scattering intensity decreases above $36{ }^{\circ} \mathrm{C}$. The polymer chains start to become insoluble due to dehydration at the $\mathrm{CP}$ and collapse into lose aggregates. This is visualized by 
Table 3. Characteristics of Copolymers $\mathrm{p}\left(\left(\mathrm{HEMAm}-\mathrm{Lac}_{2}\right)-\left(\mathrm{HEMAm}-\mathrm{Lac}_{4}\right)\right)$

\begin{tabular}{cccccc}
\hline $\begin{array}{c}\text { \% HEMAm-Lac } \\
\text { in the feed }\end{array}$ & $\begin{array}{c}\text { yield } \\
(\%)\end{array}$ & $\begin{array}{c}\text { \% HEMAm-Lac } \\
\text { incorporated }\end{array}$ & $\begin{array}{c}M_{\mathrm{w}} \\
(\mathrm{GPC})\end{array}$ & $\begin{array}{c}M_{\mathrm{w}} / M_{\mathrm{n}} \\
\left({ }^{\circ} \mathrm{C}\right)\end{array}$ \\
\hline 6 & 79 & 8 & 71000 & 3.0 & 14.5 \\
12 & 76 & 11 & 62000 & 2.8 & 9.5 \\
15 & 88 & 15 & 71000 & 2.6 & 7.0 \\
18 & 77 & 18 & 68000 & 3.0 & 5.0 \\
24 & 76 & 23 & 61000 & 2.8 & $<0$ \\
\hline
\end{tabular}

a Derived from ${ }^{1} \mathrm{H}$ NMR.

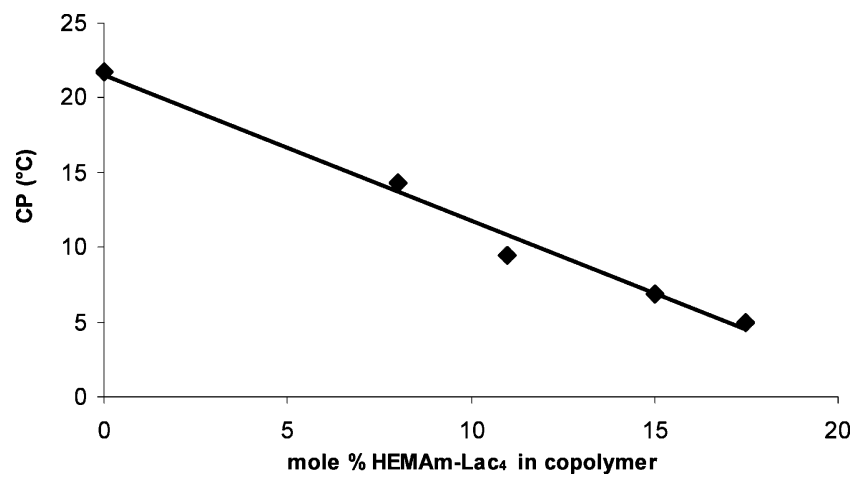

Figure 3. $\mathrm{CP}\left({ }^{\circ} \mathrm{C}\right)$ of copolymers of $p\left(\left(\mathrm{HEMAm}-\mathrm{Lac}_{2}\right)-(\mathrm{HEMAm}-\right.$ $\left.\mathrm{Lac}_{4}\right)$ ) as a function of the mole percentage of HEMAm-Lac4.

the fast increase in scattering intensity. The further increase in temperature results in full dehydration with concomitant strong intra- and intermolecular interactions and the formation of more compact aggregates that scatter less than the loose aggregates. Recently, it was found that the related polymers $\mathrm{p}\left(\mathrm{HPMAm}-\mathrm{Lac}_{1}\right)$ and $\mathrm{p}\left(\mathrm{HPMAm}-\mathrm{Lac}_{2}\right)$ had a $\mathrm{CP}$ of $63{ }^{\circ} \mathrm{C}$ and $10{ }^{\circ} \mathrm{C}$, respectively..$^{21}$ HPMAm contains an extra methyl group, which makes it slightly more hydrophobic than HEMAm. In line herewith, p(HPMAm$\mathrm{Lac}_{2}$ ) exhibits a lower CP than $\mathrm{p}\left(\mathrm{HEMA}-\mathrm{Lac}_{2}\right)$.

Copolymers p((HEMAm-Lac $)-($ HEMAm-Lac 4$))$. For practical reasons, it was aimed to obtain a polymer with a cloud point below room temperature. As reported above, the homopolymer of HEMAm- $\mathrm{Lac}_{2}$ displayed its $\mathrm{CP}$ at $22{ }^{\circ} \mathrm{C}$. To lower the CP of $\mathrm{p}\left(\mathrm{HEMAm}-\mathrm{Lac}_{2}\right)$, copolymers of HEMAm- $\mathrm{Lac}_{2}$ with the more hydrophobic monomer HEMAm- $\mathrm{Lac}_{4}$ were synthesized (Table 3).

Table 3 shows that the yields and molecular weights were comparable with those of the homopolymers (Table 2). The copolymer composition corresponded with the feed ratio. Light scattering measurements of aqueous solutions of these copolymers indeed showed that the $\mathrm{CP}$ of the copolymers linearly decreased with the amount of hydrophobic HE$\mathrm{MAm}-\mathrm{Lac}_{4}$ that was incorporated (Figure 3).

From this figure, it can be extrapolated that copolymers with more than $22 \%$ of HEMAm-Lac ${ }_{4}$ are not soluble in water at $0^{\circ}$. Indeed, the copolymer with $24 \%$ HEMAm$\mathrm{Lac}_{4}$ did not dissolve in water at $0{ }^{\circ} \mathrm{C}$ (Table 3).

Block Copolymers of PEG and HEMAm-Oligolactates. Block copolymers of PEG and HEMAm-oligolactates were synthesized by free radical polymerization using a $\mathrm{PEG}_{5000}$-substituted azomacroinitiator (Figure 4) as reported previously for the synthesis of related block copolymers. ${ }^{13,14}$

A block copolymer of PEG and HEMAm- $\mathrm{Lac}_{2}$ as well as a block copolymer with $20 \%$ HEMAm- $-\mathrm{Lac}_{4}$ and $80 \%$
HEMAm- $\mathrm{Lac}_{2}$ in the thermosensitive block were synthesized (Table 4).

Block copolymers were obtained in a high yield. ${ }^{1} \mathrm{H}$ NMR showed that the amount of HEMAm- $-\mathrm{Lac}_{4}$ incorporated in PEG- $b-\left((80 \%\right.$ HEMAm-Lac 2$)-\left(20 \%\right.$ HEMAm $\left.\left.-\mathrm{Lac}_{4}\right)\right)$ was equal to the feed ratio $(21 \%)$. Micelles were formed during heating of an ice-cold polymer solution at the cloud point (CP) of the thermosensitive part of the block copolymer, which is $6{ }^{\circ} \mathrm{C}$ for PEG- $b-\left(\left(80 \% \mathrm{HEMAm}-\mathrm{Lac}_{2}\right)-(20 \% \mathrm{HE}-\right.$ $\left.\mathrm{MAm}-\mathrm{Lac}_{4}\right)$ ). Previous research has shown that the smallest and relatively monodisperse micelles are formed by applying the so-called quick heating method. ${ }^{14}$ The rapid heating from $0-50{ }^{\circ} \mathrm{C}$ results in full dehydration of the thermosensitive blocks and promotes the formation of a compact hydrophobic micellar core. The particle size and particle size distributions are displayed in Table 4. The incorporation of $20 \%$ HE$\mathrm{MAm}-\mathrm{Lac}_{4}$ in the thermosensitive block did not only decrease the $\mathrm{CP}$ from 22 to $6{ }^{\circ} \mathrm{C}$, but also caused a significant decrease in particle size (from 124 to $80 \mathrm{~nm}$ ). Obviously, the longer hydrophobic lactic acid side chains increased the hydrophobic interactions and created a more compact micellar core. This observation is consistent with previous results from Soga et al. ${ }^{14}$

The morphology of PEG- $b-\left(\left(80 \% \mathrm{HEMAm}-\mathrm{Lac}_{2}\right)-\right.$ (20\%HEMAm-Lac 4$)$ ) micelles was studied with Cryo-TEM. Figure 5, a representative microphotograph, shows the spherical shape of the micelles as well as their narrow particle size distribution. It should be mentioned that only the core is visible as the density of the PEG is too low.

The Cryo-TEM image shows that the radius of the hydrophobic core $(R)$ of the micelles was between 10 and $23 \mathrm{~nm}$, which corresponds to radius of gyration $\left(R_{\mathrm{g}}\right)$ ranging between 8 and $18 \mathrm{~nm}$ (using equation $R=\sqrt{ }(5 / 3) R_{\mathrm{g}}$ ). Neutron scattering experiments for related block copolymers ( $\mathrm{PEG}_{5000^{-}} b$-(HPMAm- $\left.\mathrm{Lac}_{2}\right)$ ) showed that the $R_{\mathrm{g}}$ of $\mathrm{PEG}_{5000}$ is approximately $10 \mathrm{~nm},{ }^{27}$ making the values of $R_{\mathrm{g}}$ of the PEG- $b-\left(\left(80 \%\right.\right.$ HEMAm- $\left.-\mathrm{Lac}_{2}\right)-(20 \%$ HEMAm-Lac 4$\left.)\right)$ micelles between 18 and $28 \mathrm{~nm}$, which are in the range of the $\mathrm{R}_{\mathrm{g}}$ measured by SLS $\left(R_{\mathrm{g}}=31.4 \mathrm{~nm}\right.$; see section below).

The CMC was determined with pyrene as a fluorescent probe. ${ }^{24}$ The CMC was determined from the plot of the excitation intensity ratio $I_{338} / I_{333}$ as a function of the concentration of the block copolymer (Figure 6).

PEG- $b$-(HEMAm- $\mathrm{Lac}_{2}$ ) had a CMC of $0.4 \mathrm{mg} / \mathrm{mL}$ (Table $4)$, whereas PEG- $b-\left(\left(80 \%\right.\right.$ HEMAm- $\left.\mathrm{Lac}_{2}\right)-(20 \%$ HEMAm$\left.\mathrm{Lac}_{4}\right)$ ) formed micelles above a concentration of $0.08 \mathrm{mg} /$ $\mathrm{mL}$ (Figure 6). This 5-fold lower CMC for the latter system is likely because of stronger hydrophobic interactions in the core. In comparison, PEG- $b$-(HPMAm- $\mathrm{Lac}_{2}$ ) had a CMC of $0.03 \mathrm{mg} / \mathrm{mL} .{ }^{14}$ Again, due to the extra methyl group, HPMAm- $\mathrm{Lac}_{2}$ is slightly more hydrophobic than HE$\mathrm{MAm}-\mathrm{Lac}_{2}$, which results in a lower CMC.

Using the quick heating procedure, micelles were prepared from various polymer concentrations above the CMC (0.2$20 \mathrm{mg} / \mathrm{mL}$; Figure 7).

Soga et al. described that rapid dehydration of the thermosensitive segments takes place and thereby welldefined core-shell structures were formed via the quick heating procedure. ${ }^{14}$ Figure 7 shows that relatively large and 

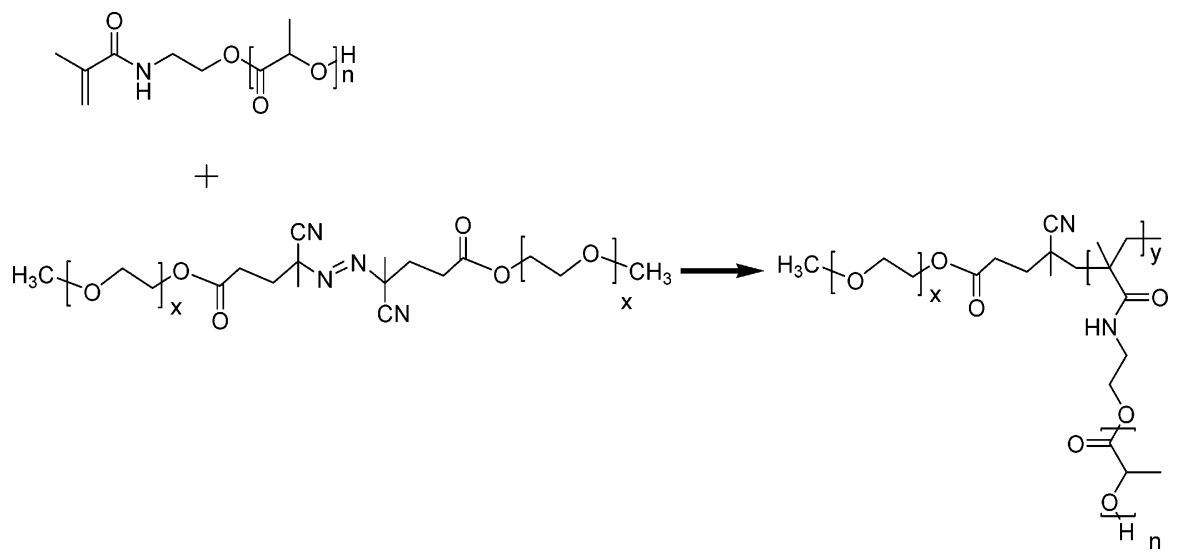

Figure 4. Synthesis of block copolymers PEG-b-(HEMAm-Lac $)$ via $P E G_{5000}$-azomacroinitiator.

Table 4. Characteristics of PEG-b-(HEMAm-Lac $\left.{ }_{n}\right)$ Block Copolymers

\begin{tabular}{|c|c|c|c|c|c|c|c|c|}
\hline block copolymer & $\begin{array}{c}\text { yield } \\
(\%)\end{array}$ & $\begin{array}{c}M_{\mathrm{n}} \\
(\mathrm{GPC}) \\
\end{array}$ & $M_{\mathrm{w}} / M_{\mathrm{n}}$ & $\begin{array}{c}M_{\mathrm{n}} \mathrm{Lac}_{n} \\
\text { block (NMR) }\end{array}$ & $\begin{array}{l}\text { CMT } \\
\left({ }^{\circ} \mathrm{C}\right)^{a} \\
\end{array}$ & $\begin{array}{c}\mathrm{CMC} \\
(\mathrm{mg} / \mathrm{mL}) \\
\end{array}$ & $\begin{array}{c}\text { micelle } \\
\text { size }\left(Z_{\text {Ave }}\right)^{a} \\
\end{array}$ & $\begin{array}{c}\text { micelle } \\
\mathrm{PD}^{a}\end{array}$ \\
\hline PEG- $b$-(HEMAm-Lac 2$)$ & 69 & 28000 & 1.5 & 10800 & 22 & 0.4 & 124 & 0.2 \\
\hline PEG- $b-\left(\left(80 \% H E M A m-\right.\right.$ Lac $\left._{2}\right)-\left(20 \% H E M A m-\right.$ Lac $\left.\left._{4}\right)\right)$ & 85 & 24000 & 1.6 & 8700 & 6 & 0.08 & 80 & 0.1 \\
\hline
\end{tabular}

a $2 \mathrm{mg} / \mathrm{mL}$ solution.

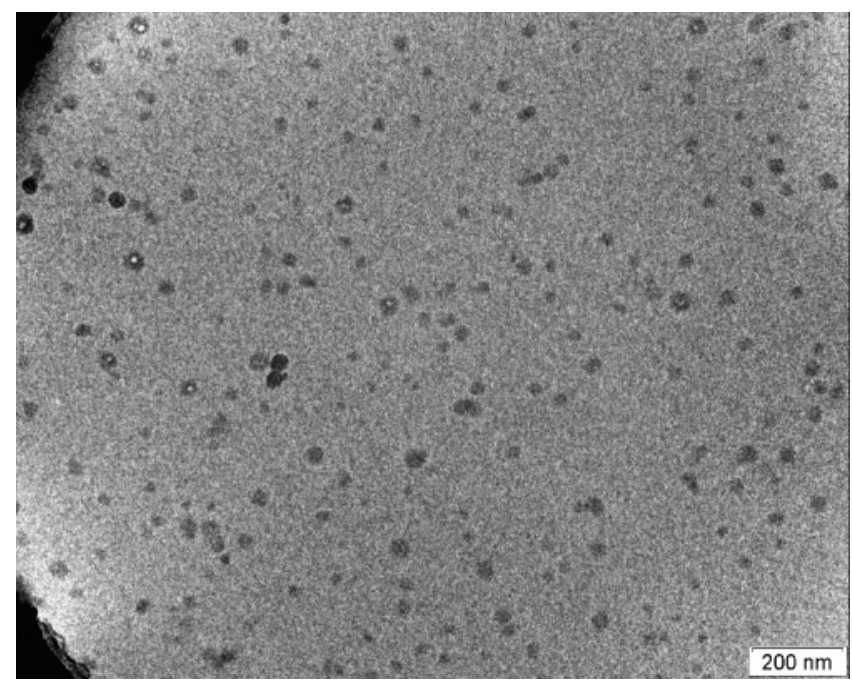

Figure 5. Cryo-TEM image of a $2 \%$ PEG- $b-\left(\left(80 \% H E M A m-\mathrm{Lac}_{2}\right)-\right.$ $\left.\left(20 \% \mathrm{HEMAm}-\mathrm{Lac}_{4}\right)\right)$ micellar solution.

polydisperse micelles are formed at concentrations below 0.5 $\mathrm{mg} / \mathrm{mL}$, which is close to the CMC. In the concentration range $0.5-10 \mathrm{mg} / \mathrm{mL}$, the particle sizes of the micelles were relatively small $(80 \mathrm{~nm})$ and their polydispersity low $(0.1-$ 0.2 ). Above this concentration, the size and PD of the micelles slightly increases, which can be ascribed to a higher probability of interpolymer aggregation at higher polymer concentrations. $^{28}$

Static Light Scattering Analysis of Polymeric Micelles of PEG- $b$ - $\left(\left(80 \%\right.\right.$ HEMAm - Lac $\left._{2}\right)-\left(20 \%\right.$ HEMAm - Lac $\left._{4}\right)$. Three micellar solutions of PEG- $b-\left(\left(80 \%\right.\right.$ HEMAm $\left.-\mathrm{Lac}_{2}\right)-$ (20\%HEMAm- $\left.\mathrm{Lac}_{4}\right)$ ) copolymers with concentrations 0.6, 0.8 and $1 \mathrm{mg} / \mathrm{mL}$ in $\mathrm{pH} 5$ buffer were measured by SLS. By extrapolating the scattered intensities to zero concentration and by plotting $\left(K c / R(q)\right.$ against $q^{2}$, both $M_{\mathrm{w}}$ and $R_{\mathrm{g}}$ were obtained from the " $y$ " intercept to zero scattering angle and from the slope, respectively. ${ }^{23}$

For PEG- $b-\left(\left(80 \% \mathrm{HEMAm}-\mathrm{Lac}_{2}\right)-\left(20 \% \mathrm{HEMAm}-\mathrm{Lac}_{4}\right)\right)$ micelles, the $M_{\mathrm{w}}$ was $27.0 \pm 1.7 \times 10^{6} \mathrm{~g} / \mathrm{mol}$ and $R_{\mathrm{g}}$ was

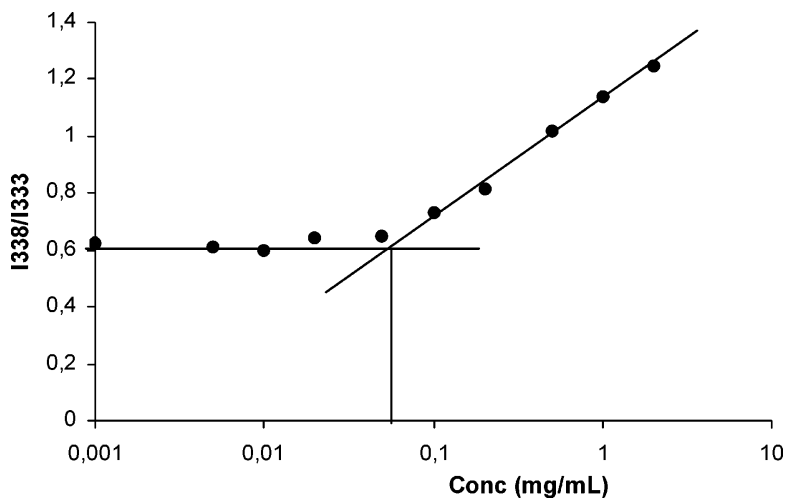

Figure 6. $/_{338} / /_{333}$ ratio for pyrene as a function of the concentrations of PEG- $b-\left(\left(80 \% \mathrm{HEMAm}-\mathrm{Lac}_{2}\right)-\left(20 \% \mathrm{HEMAm}-\mathrm{Lac}_{4}\right)\right)$ in $120 \mathrm{mM}$ acetate $\mathrm{pH} 5$ buffer. The CMC was taken from the intersections of the horizontal line at low polymer concentrations with the tangent of the curve at high polymer concentrations.

equal to $31.4 \pm 5.0 \mathrm{~nm}$. The ratio $R_{\mathrm{g}} / R_{\mathrm{h}}$ can be used to examine the morphology of the self-assembled micelles. With an $R_{\mathrm{h}}$ of $40 \pm 2 \mathrm{~nm}$ (Table 4 ), an $R_{\mathrm{g}} / R_{\mathrm{h}}$ of $0.785 \pm 0.131$ was calculated. Recently, an $R_{\mathrm{g}} / R_{\mathrm{h}}$ ratio of 0.855 was reported for a core-shell structure ${ }^{29}$ for another core-shell structure a much lower value of $R_{\mathrm{g}} / R_{\mathrm{h}}(0.66)$ was found and ascribed to a thick hydrated PEG shell. ${ }^{30}$ The $R_{\mathrm{g}} / R_{\mathrm{h}}$ value for PEG$b$-((80\%HEMAm- $\left.\left.\mathrm{Lac}_{2}\right)-\left(20 \% \mathrm{HEMAm}-\mathrm{Lac}_{4}\right)\right)$ micelles is between the values mentioned above, suggesting a coreshell structure for this system.

The aggregation number of the micelle was calculated using the equation $N_{\mathrm{agg}}=M_{\mathrm{w}} / M_{\mathrm{n}, \mathrm{o}}$, in which $M_{\mathrm{n}, \mathrm{o}}$ is the molar mass of the single copolymer chain obtained from ${ }^{1} \mathrm{H}$ NMR measurements (e.g., the $M_{\mathrm{n}}$ for PEG- $b-((80 \%$ HEMAm$\left.\left.\mathrm{Lac}_{2}\right)-\left(20 \% \mathrm{HEMAm}-\mathrm{Lac}_{4}\right)\right)$ is 13700$)$ and $M_{\mathrm{w}}$ is the weight average molecular weight of the micelle obtained from SLS. For the PEG- $b-\left(\left(80 \%\right.\right.$ HEMAm- $\left.\mathrm{Lac}_{2}\right)-(20 \%$ HEMAm$\left.\mathrm{Lac}_{4}\right)$ ) micelles, $N_{\text {agg }}$ is 1970.

The density of the micelle was calculated: $\rho_{\text {mic }}=M_{\mathrm{w}(\text { mic })} /$ $N_{\mathrm{a}} V$, where $N_{\mathrm{a}}$ is Avogadro's number and $V$ is the average 


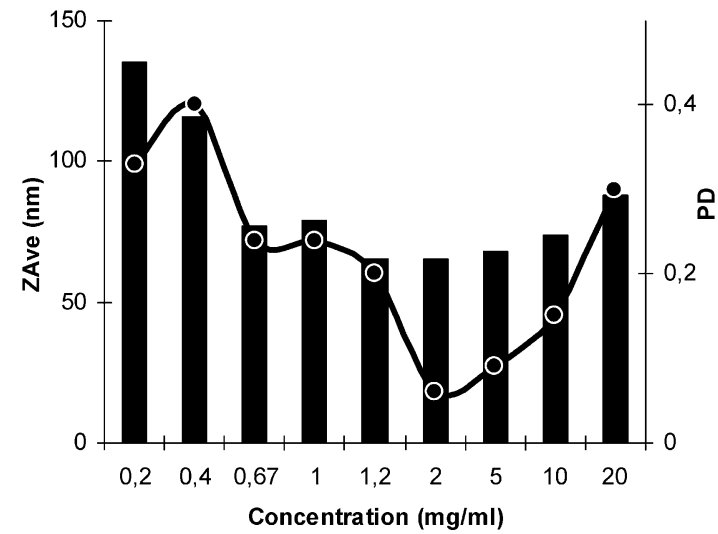

Figure 7. Size (bars) and polydispersity (dots) of PEG- $b-((80 \% \mathrm{HE}-$ MAm-Lac 2$\left.)-\left(20 \% \mathrm{HEMAm}-\mathrm{Lac}_{4}\right)\right)$ micelles solutions versus the block copolymer concentration. The measurements were done in duplo and experimental error was less than 10 percent.

volume of micelles ( $V$ was calculated via $R_{\mathrm{h}}$ ). The surface area of the micellar shell available per PEG chain $\left(S / N_{\text {agg }}\right)$ was calculated by dividing $\mathrm{S}$ (surface area of the shell of micelles calculated based on $R_{\mathrm{h}}$ ) by $N_{\text {agg. }}$. For the PEG- $b$ $\left(\left(80 \%\right.\right.$ HEMAm $\left.-\mathrm{Lac}_{2}\right)-\left(20 \%\right.$ HEMAm $\left.\left.-\mathrm{Lac}_{4}\right)\right)$ micelles, the $\rho_{\text {mic }}$ and $S / N_{\text {agg }}$ are $0.167 \mathrm{~g} / \mathrm{cm}^{3}$ and $10.2 \mathrm{~nm}^{2}$, respectively. $\mathrm{PEG}_{5000}-b$-(HPMAm- $\left.-\mathrm{Lac}_{2}\right)\left(M_{\mathrm{n}}\right.$ is 11900$)$ micelles gave comparable results with a $\rho_{\text {mic }}$ of $0.16 \mathrm{~g} / \mathrm{cm}^{3}$ and $S / N_{\text {agg }} 12.7$ $\mathrm{nm} .{ }^{14}$ The small surface area per PEG chain (i.e., higher grafting density) indicates that the micelles have a compact structure when compared to other micellar systems, e.g., PEG-PLA copolymers. ${ }^{31}$

The distance between PEG chains on the surface of nanoparticles $(d)$ is critical to avoid adsorption of plasma proteins. For instance, it has been reported that a decrease in the distance between PEG chains on the surface of polystyrene from 6.2 to $5.1 \mathrm{~nm}$ drastically decreases the adsorption of apolipoproteins up to $90 \% .^{32}$ The distance $d$ can be calculated via $\sqrt{ }(4 S) / \pi$. For the PEG- $b-((80 \% \mathrm{HE}-$ MAm- $\left.\mathrm{Lac}_{2}\right)-\left(20 \%\right.$ HEMAm- $\left.\left.\mathrm{Lac}_{4}\right)\right)$ micelles, it was calculated that the distance between neighboring PEG chains is $3.6 \mathrm{~nm}$ which will likely prevent adsorption of serum proteins.

Destabilization of the Micelles. Micelles prepared from PEG- $b$ - ((80\%HEMAm- $\left.\mathrm{Lac}_{2}\right)-\left(20 \%\right.$ HEMAm- $\left.\left.\mathrm{Lac}_{4}\right)\right)$ were incubated in a phosphate buffer of $\mathrm{pH} 7.4$ and at $37^{\circ} \mathrm{C}$ while following their size in time by DLS (Figure 8). The micelles were also incubated at $\mathrm{pH} 5$ to slow hydrolysis.

Figure 8 shows that the micelles were stable for at least $18 \mathrm{~h}$ at $\mathrm{pH}$ 5. At pH 7.4 and $37^{\circ} \mathrm{C}$, the particle size hardly changed during the first $4 \mathrm{~h}$, followed by a swelling phase until $6 \mathrm{~h}$. After that period, the micelles started to dissolve as seen by the measured scattering intensity that first increased (during 4 till $6 \mathrm{~h}$ of incubation) and then dropped until below detectable levels (after 8 h). Previously, Soga et al. showed that PEG- $b$-(HPMAm- $\mathrm{Lac}_{2}$ ) micelles dissolved after approximately one week incubation at the same (physiological) conditions. ${ }^{14}$ It was shown above (Table 1) that HEMAm-oligolactates hydrolyzed faster than the corresponding HPMAm - oligolactate monomers. In line with these results, polymeric micelles based on PEG- $b$ - ((80\%HEMAm- $\left.\left.\mathrm{Lac}_{2}\right)-\left(20 \% \mathrm{HEMAm}-\mathrm{Lac}_{4}\right)\right)$ are far more hydro-

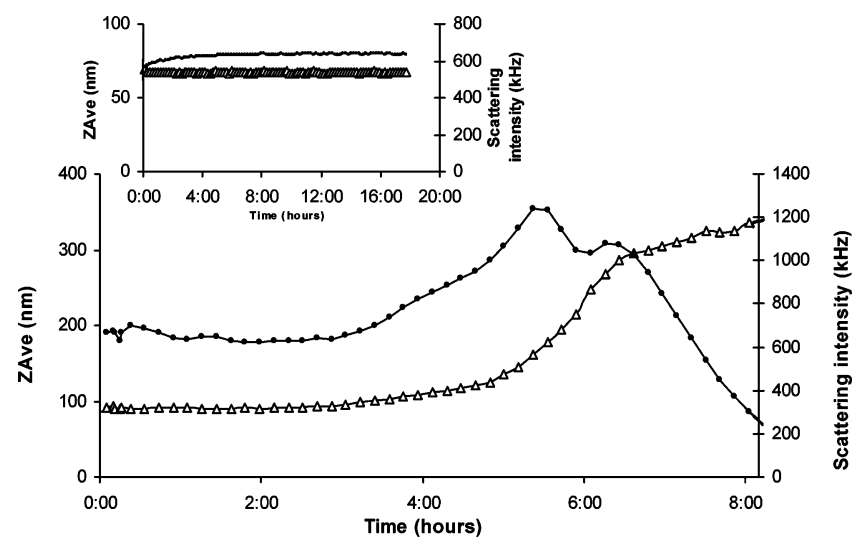

Figure 8. Size $(\triangle)$ and scattering intensity $(\bullet)$ of a $2 \mathrm{mg} / \mathrm{mL}$ PEGb-((80\%HEMAm- $\left.\left.\mathrm{Lac}_{2}\right)-\left(20 \% \mathrm{HEMAm}-\mathrm{Lac}_{4}\right)\right)$ micellar solution versus time at $\mathrm{pH} 7.4$ and $37^{\circ} \mathrm{C}$. The insert shows the size $(\triangle)$ and scattering intensity $(\bullet)$ of micelles incubated at $\mathrm{pH} 5$ and $37^{\circ} \mathrm{C}$.

lytically sensitive than the related HPMAm system and fully destabilized within $8 \mathrm{~h}$.

\section{Conclusion}

This study shows that, as anticipated, $N$-(2-hydroxyethyl)methacrylamide-oligolactates (HEMAm- $\mathrm{Lac}_{n}$ ) are more rapidly hydrolyzed than $N$-(2-hydroxypropyl)methacrylamide-oligolactates (HPMAm- $\mathrm{Lac}_{n}$ ). Thermosensitive (block co)polymers of HEMAm-oligolactates were synthesized in high yields by free radical polymerization. It appeared that the cloud point was influenced by the composition of the HEMAm-oligolactates copolymer. Furthermore, the hydrophobicity of the thermosensitive block p(HEMAm $\left.-\mathrm{Lac}_{2}\right)$ did not only influence the $\mathrm{CP}$, but also the $\mathrm{CMC}$ and the micellar particle size. Incorporation of $20 \%$ of HEMAm- $-\mathrm{Lac}_{4}$ in the thermosensitive block resulted in a low $\mathrm{CP}\left(6{ }^{\circ} \mathrm{C}\right)$, a low CMC $(0.08 \mathrm{mg} / \mathrm{mL})$ and small micelles $(80 \mathrm{~nm})$. Static light scattering measurements and Cryo-TEM pictures showed that the micelles have a compact core with a concomitant high density of PEG chains on the surface that are a prerequisite to prevent the adsorption of serum proteins. Under physiological $\mathrm{pH}$ and temperature, micelles based on PEG- $b$ $\left(\left(80 \%\right.\right.$ HEMAm- $\left.\mathrm{Lac}_{2}\right)-\left(20 \%\right.$ HEMAm- $\left.\left.\mathrm{Lac}_{4}\right)\right)$ started to swell after $4 \mathrm{~h}$ and were fully destabilized after $8 \mathrm{~h}$. This unique destabilization profile might be advantageous for in vivo use because the observed induction period is just long enough to allow accumulation of the micelles after intravenous administration at their site of action, e.g., a tumor via the EPR effect. The drug loading capacity and release behavior of these novel thermosensitive fast degrading polymeric micelles is currently under investigation.

Acknowledgment. This project is financially supported by NWO-CW/STW (Grant 790.36.110).

\section{References and Notes}

(1) Taillefer, J.; Jones, M. C.; Brasseur, N.; van Lier, J. E.; Leroux, J. C. J. Pharm. Sci. 2000, 89, 52-62.

(2) Soga, O.; Nostrum, C. F.; Fens, M.; Rijcken, C. J. F.; Schiffelers, R. M.; Storm, G.; Hennink, W. E. J. Controlled Release 2005, 103, $341-353$

(3) Hruby, M.; Konak, C.; Ulbrich, K. J. Appl. Polym. 2005, 95, 201211. 
(4) Torchilin, V. P. J. Controlled Release 2001, 73, 137-172.

(5) Gillies, E. R.; Frechet, J. M. J. Pure Appl. Chem. 2004, 78, 12951307.

(6) Bae, Y.; Fukushima, S.; Harada, A.; Kataoka, K. Angew. Chem., Int. Ed. 2003, 42, 4640-4643.

(7) Kwon, G.; Suwa, S.; Yokoyama, M.; Okano, T.; Sakurai, Y.; Kataoka, K. J. Controlled Release 1994, 29, 17-23.

(8) Storm, G.; Belliot, S. O.; Daemen, T.; Lasic, D. D. Adv. Drug Delivery Rev. 1995, 17, 31-48.

(9) Maeda, H.; Wu, J.; Sawa, T.; Matsumura, Y.; Hori, K. J. Controlled Release 2000, 65, 271-284.

(10) Oh, K. T.; Bronich, T. K.; Kabanov, A. V. J. Controlled Release 2004, 94, 411-422.

(11) Rapoport, N.; Pitt, W. G.; Sun, H.; Nelson, J. L. J. Controlled Release 2003, 91, 85-95.

(12) Topp, M. D. C.; Dijkstra, P. J.; Talsma, H.; Feijen, J. Macromolecules 1997, 30, 8518-8520.

(13) Neradovic, D.; van Nostrum, C. F.; Hennink, W. E.; Macromolecules 2001, 34, 7589-7591.

(14) Soga, O.; Nostrum, C. F.; Ramzi, A.; Visser, T.; Soulimani, F.; Frederik, P. M.; Bomans, P. H. H.; Hennink, W. E. Langmuir 2004, 20, 9388-9395.

(15) Moghimi, S. M.; Hunter, A. C.; Murray, J. C. Pharmacol. Rev. 2001, $53,283-318$

(16) Neradovic, D.; van Steenbergen, M. J.; Vansteelant, L.; Meijer, Y. J.; van Nostrum, C. F.; Hennink, W. E. Thesis, 2003.

(17) Neradovic, D.; Hinrichs, W. L. J.; Kettenes-van den Bosch, J. J.; Hennink, W. E. Macromol. Rapid Commun. 1999, 20, 577-581.

(18) Song, J.; Saiz, E.; Bertozzi, C. R. J. Am. Chem. Soc. 2003, 125 , $1236-1243$.

(19) van Dijk-Wolthuis, W. N. E.; Tsang, S. K. Y.; Kettenes-van den Bosch, J. J.; Hennink, W. E. Polymer 1997, 38, 6235-6242.
(20) Nostrum, van C. F.; Veldhuis, T. F. J.; Bos, G. W.; Hennink, W. E. Polymer 2004, 45, 6779-6787.

(21) Soga, O.; Nostrum, C. F.; Hennink, W. E. Biomacromolecules 2004, $5,818-821$.

(22) Gil, E. S.; Hudson, S. M. Prog. Polym. Sci. 2004, 29, 1173-1222.

(23) Zimm, B. J. Chem. Phys. 1948, 16, 1099-1116.

(24) Wilhelm, M.; Zhao, C.; Wang, Y.; Xu. R.; Winnik, M. A.; Mura, J.; Riess, G.; Croucher, M. D. Macromolecules 1991, 24, 1033-1040.

(25) de Jong, S. J.; Arias, E. R.; Rijkers D. T. S.; van Nostrum, C. F.; Kettenes-van den Bosch, J. J.; Hennink, W. E. Polymer 2001, 42, 2795-2802.

(26) Patai, S. The chemistry of carboxylic acids and esters; WileyInterscience: London, 1969; p 520.

(27) Ramzi, A.; Soga, O.; Veldhuis, T. F. J.; Rijcken, C. J. F.; Schwahn, D.; Nostrum, C. F.; Hennink, W. E. Manuscript in preparation.

(28) Neradovic, D.; Soga, O.; Van Nostrum, C. F.; Hennink, W. E. Biomaterials 2004, 25, 2409-2418.

(29) Dai, S.; Ravi, P.; Leong, C. Y.; Tam, K. C.; Gan, L. H. Langmuir 2004, 20, 1597-1604.

(30) Palaniswamy, R.; Dai, S.; Tam, M. K. C.; Gan, L. H. Molecular Engineering of Biological and Chemical Systems (MEBCS), http:// hdl.handle.net/1721.1/3938, 2004.

(31) Riley, T.; Heald, C. R.; Xiong, C. D.; Garnett, M. C.; Illum, L.; Davis, S. S.; Purkiss, S. C.; Barlow, R. J.; Gellert, P. R. Langmuir 2001, 17, 3168-3174.

(32) Soppimath, K. S.; Aminabhavi, T. M.; Kulkarni, A. R.; Rudzinski, W. E. J. Controlled Release 2001, 70, 1-20.

BM0502720 